This article is available in PDF-format, in colour, at:

http://www.wydawnictwa.ipo.waw.pl/materialy-wysokoenergetyczne/materialy-wysokoenergetyczne12_1/HEM_0158_E.pdf

Materiaty Wysokoenergetyczne / High Energy Materials, 2020, 12 (1), 17 - 36; DOI 10.22211/matwys/0158E ISSN 2083-0165

Copyright (C) 2020 Lukasiewicz Research Network - Institute of Industrial Organic Chemistry, Poland

(C) $\$$ BY $९$ NC Article is available under the Creative Commons Attribution-Noncommercial-NoDerivs 3.0 license CC BY-NC-ND 3.0.

Review / Przegląd

First published in Polish in 2017.

\title{
Aspects of nanomaterials for civil and military applications. Part 2. Their use and concerns arising from their release into the natural environment Aspekty nanomateriałów w zastosowaniach cywilnych $i$ militarnych. Część 2. Wykorzystanie i obawy wynikające $\mathrm{z}$ ich uwalniania do środowiska przyrodniczego
}

\author{
Zenon Foltynowicz ${ }^{1)}$, Bogdan Czajka ${ }^{2)}$, Andrzej Maranda ${ }^{3)}$, Leszek Wachowski, ${ }^{4, *)}$ \\ 1) University of Economics and Business, Faculty of Commodity Science, 10 Niepodległości Avenue, \\ 61-875 Poznań, Poland \\ 2) Institute of Non-Ferrous Metals** in Gliwice, Poznań Branch, 12 Forteczna Street, 61-362 Poznań, Poland \\ 3) Military University of Technology, 2 gen. S Kaliskiego Street, 00-908 Warsaw, Poland \\ 4) Adam Mickiewicz University, Faculty of Chemistry, 89b Umultowska Street, 61-614 Poznań, Poland \\ *E-mail:wachow@amu.edu.pl \\ ** at present: Lukasiewicz Research Network - Institute of Non-Ferrous Metals
}

\begin{abstract}
The dynamic development of nanoscience and nanotechnology has led to revolutionary changes in many areas of science and industry, raising a great deal of hope for its potential to solve a wide range of problems of the modern world. Nanomaterials, also referred to as engineered nanoparticles are a product of nanotechnology and, compared to macro-particles, show unique physical, chemical, biological and mechanical properties which significantly extend the range of practical applications. The paper presents the applicability of engineered nanoparticles in the defence industry and concerns related to their release into the environment.

Streszczenie: Dynamiczny rozwój nanonauki i nanotechnologii sprawit, że w wielu dziedzinach nauki $i w$ sektorach przemystu zachodza rewolucyjne zmiany budzac ogromne nadzieje na potencjalna możliwość rozwiazania całego szeregu istotnych problemów wspótczesnego świata. Nanostrukturalne materiały określane też mianem nanoczqstek inżynierskich stanowiace produkt nanotechnologii wykazuja w porównaniu do swoich odpowiedników w skali makro unikatowe właściwości fizyczne, chemiczne, biologiczne $i$ mechaniczne. Wszystko to sprawia, że znajduja one coraz szersze praktyczne zastosowanie. W pracy zaprezentowano możliwości stosowania nanoczastek inżynierskich ze szczególnym uwzględnieniem sektora obronnego oraz obawy wynikające $z$ ich uwalniania do środowiska przyrodniczego.
\end{abstract}

Keywords: nanomaterials, nanoproducts, military nanomaterials, environmental aspects Stowa kluczowe: nanomateriały, nanoprodukty, nanomateriały militarne, aspekty środowiskowe 


\section{Foreword}

Nanotechnology is a thriving science sector aimed at developing new fabrication technologies for various materials and devices in nanoscale, also referred to as nanomaterials, nanoobjects or engineered nanoparticles (NPs), at the lowest cost [1-19]. The unique properties of nanomaterials resulting from their internal structure are at the boundary of materials science. The practical applicability of those unique but not yet thoroughly analysed physical, chemical and biological properties and the effects of those materials, make them a valuable raw material for many innovative products. The NPs are in practical use in virtually all areas of life, as additives, fillers and components of nanocomposites [1, 6-8, 12, 18, 20-27].

In the last decade, due to the properties of nanomaterials and an extensive practical applicability of nanotechnology, the average annual growth rate of use of nanomaterial-based products has reached $50 \%$ [28]. Analysts report that the nanotechnology market in 2020 will reach 41.8 billion USD $(10.2 \%$ increase since 2015) with a predicted increase in investments, both public and private, in research and development in nanotechnology and the commercialization of nanoproducts [29]. In 2005, the Woodrow Wilson International Center for Scholars established the Nanotechnology Consumer Products Inventory (CPI). In 2015, according to the latest report [30], 1814 nanoproducts and over 1600 manufacturers are present on the global market. According to another report [31], 3 to 4 new nanoproducts are introduced into the market every week.

The basic engineered nanomaterials include:

a) nanometals which, similar to their macro equivalents, are polycrystalline materials [1, 4, 5, 12, 15-19]. Miniaturization of a conventional material resulting in a reduction in grain size and an increase in surface area by volume gives them their unique properties, including high chemical reactivity due to a high specific surface area, pyrophoric properties, corrosion resistance and high nanomaterial strength which can be further increased by adding different phase particles $[4,5,12]$.

Tests carried out using metallic aluminium powder $(\mathrm{Al})$ showed that with a decrease in particle size, the number of atoms on the surface increases rapidly, corresponding to an increase in chemical reactivity and pyrophoric properties [32-38]. The following metals are usually miniaturized: aluminium $(\mathrm{Al})$, copper $(\mathrm{Cu})$, iron $(\mathrm{Fe})$, nickel $(\mathrm{Ni})$, cobalt $(\mathrm{Co})$, platinum $(\mathrm{Pt})$, palladium $(\mathrm{Pd})$, silver $(\mathrm{Ag})$, gold $(\mathrm{Au})$, achieving a grain size of several nm [11-16, 19, 34-36]. Absorption of electromagnetic radiation (UV-VIS) by metallic NPs depends on their size and shape. This relationship is used to determine the nanoparticle parameters based on their absorption spectra $[3,5,11,18]$.

Variations in energy released during oxidation of a specific metal depending on the degree of dispersion, means that the metal can be used as a component of high-energy materials in many different applications, including explosives, underwater explosive ordnances, primers, rocket fuels and pyrotechnic materials for military and mining applications $[2,8,12,16-20,32-42]$;

b) nanooxides: titanium(IV) $\left(\mathrm{TiO}_{2}\right)$, silicon(IV) $\left(\mathrm{SiO}_{2}\right)$, cerium(IV) $\left(\mathrm{CeO}_{2}\right)$, zirconium(IV) $\left(\mathrm{ZrO}_{2}\right)$, zinc(II) $(\mathrm{ZnO})$, iron(III) $\left(\mathrm{Fe}_{2} \mathrm{O}_{3}\right)$, yttrium(III) $\left(\mathrm{Y}_{2} \mathrm{O}_{3}\right)$ and other oxides [19, 37-51];

c) nanoceramic materials, characterised by significantly higher tolerance of the coating to ambient conditions compared to conventional coatings, including high temperature, significantly higher durability, abrasion, wear and corrosion resistance, such as $\mathrm{Al}_{2} \mathrm{O}_{3} / \mathrm{Ni}, \mathrm{Al}_{2} \mathrm{O}_{3} / \mathrm{SiC}, \mathrm{Si}_{3} \mathrm{~N}_{4}, \mathrm{Si}_{4} \mathrm{C}, \mathrm{AlN}$ :

- ionic ceramic materials: alumina $\left(\mathrm{Al}_{2} \mathrm{O}_{3}\right)$, zirconia(IV) $\left(\mathrm{ZrO}_{2}\right)$ characterized by high melting point and strain resistance;

- covalent ceramics - a combination of two non-metals including $\mathrm{SiO}_{2}, \mathrm{SiC}, \mathrm{B}_{4} \mathrm{C}$ - good thermal and electrical insulators $[12,16,20,31,46-54]$.

The development of nanotechnologies opened a path to creating various layers which could not be obtained using conventional materials. Applying engineered NPs to the surfaces of solids creates layers showing superhydrophobic, self-cleaning or anti-bacterial properties. The developments in nanotechnology allow the creation of layers with unique sensory, catalytic, sorptive, electron and biological properties $[1-8,15$, $16,31,48]$;

d) nanopolymers include amorphous particles with a common core formed by carbon atoms with covalent bonds which undergo glass transition and flow at given temperatures: 
- thermoplastics which easily change into viscous liquid (e.g. polystyrene, polyethylene, polyamides) $[1,2$, $4,8,12,13,15,20,55,56]$,

- cross-linked nanoresins (e.g. external laminate-glass, polyester-glass and epoxy-glass layers) [2, 15, 20],

- rubber-like elastomers and natural products including cellulose, lignin and proteins $[2,8,13]$,

- nanofillers used in rubber and plastics [57-59],

- nanopolymer-based Porsche Classic car care products for car body care [60],

- nanobiopolymers used as excellent thermal insulators [61].;

e) nanocomposites including two components (similar to traditional composites), one used as a binding agent (e.g. montmorillonite) and another used as a structural element (e.g. glass fibre, quartz, asbestos, carbon fibre):

- metallic [62],

- ceramic $[63,64]$,

- polymer used as a filler (e.g. MMT, montmorillonite-polyethylene, polypropylene or polyamides) $[57,65]$;

f) carbon nanostructures including amorphous carbon $(\mathrm{C}$, soot), fullerenes, nanotubes, graphene, igraphene [hydrogenated graphene, 2D polymer], with the first three used in the most practical applications [66-79];

g) materials based on elements with allotropes showing structure similar to graphene, including silicone ( $\mathrm{Si}$ ), germanene $(\mathrm{Ge})$, tinene $(\mathrm{Sn})$, phosphorene $(\mathrm{P})[80,81]$.

\section{Applications of nanomaterials in civil industries}

The list of products manufactured using engineering NPs for use in civil industries includes over 4,000 products and is constantly growing. Nanosilver is most commonly used in the end products [29]. In many cases, civilian applications correspond to those in the military sector [2, 3, 5, 12-16, 19, 27].

USA, China, South Korea, India, Brazil and the Netherlands are significant developers of nanotechnology [28]. The civil industries manufacturing or using engineered NPs in the end products include:

a) Chemical industry with products containing NPs, include:

- catalysts, with the largest share of approx. $53 \%$ used in heterogenous, homogenous and electro-catalytic industrial processes, including: nanoporous zeolites [82-84], Raney nickel [82], nanocrystalline electrode made of copper converting carbon monoxide $(\mathrm{CO})$ to ethanol $\left(\mathrm{C}_{2} \mathrm{H}_{5} \mathrm{OH}\right)$ [84], nanoporous gold $(\mathrm{Au})$ used as an active and selective catalytic material with huge potential applications in heterogenous, homogenous and electro-catalytic industrial processes [85-87],

- amorphous carbon (C), i.e. soot used in the rubber industry for tyre manufacturing [17],

- aerogel $\left(\mathrm{SiO}_{2}\right)$ - a stiff foam with very high porosity up to $99.8 \%$ showing excellent insulating properties [88],

- surfactants [89, 90],

- dyes [91],

- corrosion-resistant coatings [91].;

b) Electronics industry, with up to $7 \%$ of products containing nanomaterials; the main products include:

- semiconductors (most common) with a market share estimated at $34 \%$ [2, 5, 12, 19, 92],

- organic light-emitting diodes, superconductors, transistors, ferromagnetics [19, 40, 91],

- nanostructural magnets used in mobile phones and hard drives in personal computers $[15,16,19,27$, 67-70, 75, 84, 93],

- devices used in wireless communication [12, 15, 67, 93, 94],

- nanocrystalline phosphorus (P) used in displays providing high resolution images $[2,12,15,16]$,

- new generation portable computers for medical applications [2, 12, 13, 16, 19],

- streetwear with monitoring functions (heart rhythm and blood pressure) [95, 96],

- fluorescent clothing or clothes maintaining constant body temperature, e.g. Italian Luminex ${ }^{\circledR}$ fabric includes light-emitting diodes (LEDs) (wedding dresses, glossy cocktail dresses or opera singer costumes [95-98].; 
c) Construction industry, using:

- light and high mechanical strength materials containing engineering NPs include: photovoltaic coatings, window coatings, anti-bacterial coatings, acoustic baffles, blind spot traffic mirrors, ceramic and metal facades [99-101],

- products increasing the resistance of ceramic surfaces of building materials as a result of hydrophobic treatment $[102,103]$;

d) Urban economy, using engineered NPs to:

- treat and disinfect water, including adsorbents (e.g. nanoporous carbons), ceramic and polymer membranes, nanotubes, Nano Silver Aqua [91, 104-106],

- removing microorganisms from water environment using carbon nanotubes in filters and membranes, nanosilver $(\mathrm{Ag})$, which at $10 \mathrm{~g} / \mathrm{m}^{3}$ inhibits growth of Escherichia coli, nanochitosan containing copper $(\mathrm{Cu})$ and magnetic composites eliminating Microcystis aeruginosa blue-green algae [91, 107-109],

- removing heavy metals from wastewater using nanomaterial-based adsorbents, e.g. core-shell nanosystems [91, 110],

- $\quad$ air treatment using nanoporous filters and membranes [111].;

e) Aviation industry (aircraft, spacecraft and satellite manufacturing), using ceramic plates increasing and improving durability and providing reliable operation at high temperatures. Carbon nanotubes are used to reinforce aircraft fuselages $[12-19,39,40,84,95,96]$;;

f) Car industry, with a nanomaterial share of approx. $1 \%$, using:

- three-way catalysts (TWCs) for neutralizing exhaust gases from internal combustion engines [82, 112],

- ceramic nanocomposites and carbon fibres as a structural material for car braking systems [82, 113],

- polyester films (several nanometres thick) for marking vehicles and components [82],

- high durability paint coats based on silica NPs $\left(\mathrm{SiO}_{2}\right)$ [114],

- dashboards, body panels, petrol tanks using barrier properties of different nanocomposites in ceramicmetal, ceramic-polymer and metal-polymer systems [115].;

g) Food industry, using $1 \%$ of nanomaterials:

- $\operatorname{nanosilver~(Ag)~for~food~preservation~and~pasteurization~[116],~}$

- nanosilver (Ag) used by Samsung in Silver Nano Health System to limit bacterial growth in fridges and Bosch/Siemens in System Anti-Bacteria, in washing machines, vacuum cleaners and air conditioners [117].;

h) Medical applications, using $2 \%$ of nanomaterials (rapidly growing):

- bioactive glass showing anti-bacterial properties replacing conventional fillers, used in metabolic processes and permanently bonding to tissues, e.g. calcium aluminium borosilicate, sodium calcium phosphosilicate [118, 119],

- piezoelectric material, binary oxide $(\mathrm{PZT})\left[\mathrm{PbZr}_{(\mathrm{x})} \mathrm{Ti}_{(1-\mathrm{x})}\right] \mathrm{O}_{3}$ generating electric energy due to mechanical stresses in the organism used as a pacemaker power supply [120],

- glass-ceramic composite used to repair bone defects in spine, ilia and knee joints [121],

- different products used in chemotherapy which combined with a specific biopolymer (e.g. protein, saccharide, lipids or polyesters) can be used as matrices for vaccines [122],

- NPs of silver $(\mathrm{Ag})$ and gold $(\mathrm{Au})$ and their alloys in colloidal systems used to eliminate staphylococcus bacteria resistant to antibiotics; nanosilver $(\mathrm{Ag})$ is an innovative bactericide or fungicide [123],

- intelligent magnetic NPs used in targeted drug dosing, as a markers for ultrasensitive detection and gene therapy and as biochemical sensors and agents for rapid decontamination [124],

- nanoelectrodes (sensors) for in vitro measurements of $\mathrm{NO}_{\mathrm{x}}$ content in single brain cells [125-127].;

i) Cosmetics industry, using nanomaterials in different cosmetics, sanitary and other products, e.g.:

- face cream, sunscreens (UV filters) containing mineral filters made of titanium(IV) oxide and zinc oxide ( $\mathrm{ZnO})$ NPs from 1-30 nm [128-130],

- Nanoco Nano Silver Aqua products, containing silver (Ag) and copper $(\mathrm{Cu})$ NPs used as bactericides and fungicides in swimming pools, aquariums, and Faruk Chi Nano containing silver (Ag) NPs for impregnation of fabrics and coatings preventing soiling and microbial growth [131].; 
j) Packaging industry manufacturing nanomaterial based products:

- print protecting agents based on phosphate(V) NPs or rare earth elements (RE) [132],

- invisible gold $(\mathrm{Au})$ and silver $(\mathrm{Ag})$ barcodes [133],

- aluminium NPs-based fuel tanks with improved security [132, 134],

- polymer nanocomposites - modified bentonites as used as plastic fillers in modern packaging [132, 135],

- metal NPs as dioxygen $\left(\mathrm{O}_{2}\right)$ absorbents in packaging [136-147].

\section{Applications of nanomaterials in the military industry}

A significant increase in investment in nanoscience produced numerous innovative solutions using nanotechnology, appreciated and implemented by the defence industry [12, 16, 19, 39, 40, 148, 149, 151]. Literature shows that the share of nanotechnology products in this industry is estimated at approximately $3 \%$ and the products are used throughout the industry $[3,5,19,148,149]$. The advantages of practical applications of innovative nanotechnology solutions in the defence industry are:

a) developing new generation armaments based on nanotechnology [12, 16, 19, 39, 40, 152, 153],

b) significant decreases in dimensions and weight with similar or improved effectiveness $[3,5,8,12,16$, $19,39,40]$. It allows the design of significantly smaller nuclear charges with similar effectiveness, which is a serious challenge in limiting and controlling nuclear weapons [12, 19, 39, 40,98]. Ability to significantly decrease the weight of man-carried equipment with the same functionality, increased mobility, strength and range of operation [16, 19, 39, 40, 154-157],

c) modifications of the effectiveness of warfare agents including:

- composite high energy materials (high explosives, HE) modified to introduce different metallic nanopowders (aluminium $(\mathrm{Al})$, copper $(\mathrm{Cu})$, platinum $(\mathrm{Pt})$, palladium $(\mathrm{Pd})$ ). The modifications significantly increase the chemical reactivity and temperature of the detonation products. A significant increase in the rate in which the balance of the decomposition product distribution is achieved and improved pyrophoric properties, further increasing the effectiveness, can also be observed $[9,11,16,19,21,33$, $39,40,122,153,156-165]$.,

- thermites, also referred to as Goldschmidt thermites or pyrotechnic compositions containing a metallic powder used as a reducer mixed in a specific ratio with a metal oxide used as an oxidizer and a fuel used as a reaction initiator. The oxidation of metallic powder is rapid with simultaneous release of a large amount of heat $(Q)$, e.g.:

$2 \mathrm{Al}+\mathrm{Fe}_{2} \mathrm{O}_{3} \rightarrow \mathrm{Al}_{2} \mathrm{O}_{3}+2 \mathrm{Fe}+Q$

Replacing the metallic powder and metal oxide powder in conventional thermites with suitable nanomaterials yields new products referred to as nano-thermites or super-thermites, in which the metal oxidation reaction is in some cases a thousand times quicker and is accompanied by a very reactive positive pressure wave $[12,16,19,157]$.

The additives known as super-thermites are used to produce high-power warfare agents. The supertermites are obtained by combining nanometals (e.g. nanoaluminium (Al)) with metal oxides (e.g. iron(III) oxide, $\mathrm{Fe}_{2} \mathrm{O}_{3}$ ) used in underwater explosive ordnances, low explosive primers and rocket fuels. The addition of nanopowders, e.g. aluminium (Al) increases the energy of propellant and blasting materials, gunpowders and thermites. The nanomaterials allow a significant reduction in the charge and fuel weight without affecting the effectiveness of the weapon system [166].

Metastable intermolecular composites (MICs), e.g. $\mathrm{Al} / \mathrm{MoO}_{3}, \mathrm{Al} / \mathrm{PTFE}$ and $\mathrm{Al} / \mathrm{CuO}$ composites are one of the first examples of developments in nanoenergetics [12, 16, 19, 39, 40, 98].,

- solid and liquid rocket fuels, where the significant advantages of nanofication is the ability to obtain higher power densities, increase the combustion rate and reduce the ignition delay of the final product $[12,16,19,48,98,152,155,156,164-169,188]$, 
- advanced ammunition and warheads obtained as a result of:

i) replacing depleted uranium (U) cores in armour-piercing sabot shells with nanocrystalline tungsten (W) for easy penetration of combat vehicle armour [5, 12, 16, 19, 39, 40, 121, 170, 173],

ii) using sinters of heavy nanomaterials for manufacturing sabot shell and armour piercing shells cores; the best materials include tungsten (W) sinters showing high durability and plasticity $[12,16,17$, $19,39,40,98,153,170-174]$,

iii) gradual replacement of toxic lead shells with nanoaluminium (Al) shells [12, 16, 19, 39, 40, 98, 175].;

- nanomaterials used in armours of personal vehicles, combat vehicles, ships and aircrafts. A spectacular example is the manufacturing technology of ceramic armour materials based on boron carbide $\left(\mathrm{B}_{4} \mathrm{C}\right)$ nanopowder developed by a Russian company $\mathrm{NeVz}[19,176,180,188]$. The materials are used to manufacture combat vehicle armour and individual bulletproof plates, improving the efficiency 5-6 times while maintaining 4-times lower weight. Numerous studies showed that the nanostructure of materials based on iron alloys allows a significant increase in impact resistance [176-182]. The products commonly used to manufacture advanced combat vehicle armour, reinforcing the structure of ships' hulls and aircraft fuselages are aluminium alloys combined with carbon nanotubes with improved impact resistance, durability and lower weight $[12,16,19,39,40,66,98,183]$;

d) ability to manufacture new materials and items based on the recently developed products, including new forms of elemental carbon (C), graphene, nanotubes and fullerenes [12, 16, 19, 39, 40, 66, 76, 98, 184-188],

e) innovative auxiliaries including:

- optical materials for designing innovative communication systems including new methods to control, transfer and transmit photonic information $[12,16,19,39,40,76,98,118,119,184,188,190]$,

- IR detectors (quantum and thermal), carbon nanotubes as the first IR nano-detectors [19, 74, 98, 118, 188-190],

- metamaterials for designing systems with negative refractive index; the objects coated with this material may be invisible in a limited electromagnetic radiation bandwidth $[4,8,12,19,39,40,98,188,191,192]$,

- materials which reversibly change the characteristics of light transmission depending on ambient temperature, radiation intensity, incident UV wavelength [12, 19, 98, 193-196].

For the first time, those materials were used in 1964 for tinting photochromic lenses (sunglasses) containing silver halide $(\mathrm{AgX}) \mathrm{NPs}$, where the silver ions $\left(\mathrm{Ag}^{+}\right)$under $\mathrm{UV}$ radiation reversibly change their electron structure $\left(\mathrm{Ag}^{+} \leftrightarrow \mathrm{Ag}^{0}\right)$. The lenses react to the ambient conditions, and the degree of tinting depends on ambient temperature and exposure to adaptive radiation. Later introduced photonic materials, based on organic liquid crystals, due to longer time of reaction to UV, susceptibility to damage by ambient conditions and high production costs, were not widely used [193]. Currently, vanadium dioxide $\left(\mathrm{VO}_{2}\right)$ suspended in a silica matrix $\left(\mathrm{SiO}_{2}\right)[119,194]$, rare earth elements (RE) and selected transition metals [196], are used as photonic materials for coating large surfaces. The composites are durable and can be used to coat large surfaces, e.g. aircraft fuselages and ships' hulls, they are costeffective and can be used in fabrication of [19, 193-196].,

- energy storage materials $[12,19,98,152,155]$,

- heat storage materials $[12,19,39,40,188]$,

- control materials for advanced electronic systems,

- information processing systems [12, 19, 39, 40],

- nanostructural magnets in mobile phones [5, 12, 19, 40, 96, 98],

- drives in personal computers and portable devices [12, 19, 39, 40],

- wearable computers for military, medical and industrial applications [12, 16, 19, 39, 40, 96],

- structural materials for military installations, e.g. missile launcher rails where the propellant deflagration provides high velocities $[5,12,19,39,40,96,98,101]$;

f) Materials for manufacturing next generation uniform components and equipment (i.e. weapons, ammunition, electronic equipment and power sources) $[5,12,16,19,39,40,84,97,197-202]$.

Innovative nanotechnology solutions allow the development of more efficient tools for solving problems which 
soldiers encounter in the battlefield. The most significant advantages include:

- an ability to significantly decrease the weight of soldiers' equipment with the same functionality for improved mobility, strength and range of operation [16, 19, 97, 154, 197-202],

- $\quad$ ability to quickly deal with any injuries [19, 39, 40, 157, 197, 200, 201],

- innovative means of improving or sustaining a soldier's efficiency, e.g. in sleep deprivation conditions $[156,157,200]$,

- uniforms made of multi-functional and smart adaptable materials which, in the event of injury, will automatically dress the wound [12, 19, 97, 98, 197, 200],

- innovative systems built into the uniform for detecting and neutralizing chemical and biological contamination; interactive materials providing not only a passive protection but in the future providing protection against nuclear and electromagnetic radiation [12, 19, 39, 40, 97, 197-201],

- new synthetic fibres, e.g. aramid fibre available under tradename Kevlar ${ }^{\mathbb{B}}$ - one of the most durable synthetic fibres (five times stronger than steel) used in bulletproof vests [19, 97, 98, 197, 201, 203],

- nanofoams with unique thermal and insulating properties [19, 97, 98, 197, 201-204],

- ultralight clothing and footwear and heated headgear, gloves and socks [12, 97, 98, 201, 204],

- Nano-Care fibre clothing made of $100 \%$ twill weave cotton impregnated with engineered NPs for improved durability, stain and moisture resistance (breathable fabric) [204],

- uniforms with a camouflage system (so called adaptive camouflage) protecting soldiers against detection on the battlefield [19, 97, 98, 197, 201, 204].

The Institute for Soldier Nanotechnologies was established in 2002 in the USA, consisting of the US Army Research Laboratory, Massachusetts Institute of Technology and industry sectors. Working closely together, the institutes cooperate on projects aimed at preparing self-sufficient soldiers to easily deal with extreme and hard to anticipate situations $[19,197,199,204]$. Survivability increases significantly due to the use of flexible armours with nanofiber matrix, e.g. $\mathrm{SiC}[84,197,198,201,204]$.

The U.S. Army Natick Soldier Systems Center (NSSC) is the only institute in the world focused on developing the Future Warrior Concept (FWC) [199]. Its aim is the development of a multi-functional battlesuit using the latest developments in nanotechnology [197]. NSSC also develops special light and comfortable gear monitoring the condition, health and stress level of soldiers and supporting the treatment of wounds [12, 19, 40, 197-204].

\section{Emerging applications of engineered NPs}

Attempts are being made to finalize the ongoing research programmes and develop new methods for the practical use of the unique properties of engineered NPs. The following projects aimed at developing new innovative NPs are noteworthy:

- chemical composition of low vulnerability high-energy materials, releasing energy in the amount necessary for its intended application including ammunition, rocket fuels and thermobarics, multi-functional charges by the Armament Systems and Procedures, Inc. (ASP) [12, 19, 39, 40, 173, 196],

- methods to manipulate energy flow between the particles and their surroundings and physical fields referred to as nanoenergetics to develop weapons characterized by a significantly higher impact energy $[5,12,16,19$, $39,40,98,152,155]$,

- compositions of explosives using suitable nanomaterials for significantly increased power [12, 16, 19, 39, $40,154,173,188]$,

- design of nuclear weapons of significantly smaller size referred to as mini-nukes $[12,16,19,39-43$, $121,141]$; a serious challenge in limiting and controlling nuclear weapons [12, 39, 40],

- products for use in the construction industry, including windows with quantum dots used as solar panels [12, 19, 101, 103],

- high-adhesion materials similar to gecko feet [12, 19, 149, 152],

- bullet-proof suits made of ultra high molecular weight polyethylene (UHMPE) [12, 19, 97, 98, 201-204],

- Tactical Assault Light Operator Suit (TALOS), providing full-body ballistic protection [19, 97, 98, 197, 204], 
- engineered nanomaterials, including complex polymers with large molecules and a well-defined structure referred to as dendrites, e.g. flower-shaped anatase $\mathrm{TiO}_{2}$ mesostructure [12, 19, 39, 40-43, 188],

- polymer materials with embedded engineered NPs (e.g. Au/MoS $)$ with high resistance to abrasion and good sliding properties used as lubricant-free machine components [12, 19, 40, 182, 200-210],

- materials resistant to high temperatures, e.g. ceramics [10, 12, 16, 19, 32, 84, 208-210],

- nanocrystalline materials used as functionally gradient materials (FGMs) in electronic and biomedical devices [12, 19, 39, 40, 98, 152, 188, 207, 208, 211],

- implants based on carbon and oxide nanomaterials [5, 12, 19, 91, 157, 201, 211],

- electronic devices for transmission of information, night vision and navigation, and various sensors (e.g. motion, condition of equipment and ammunition) [5, 12, 16, 19, 39, 40, 92-95, 208, 212].

The examples of applications of innovative nanotechnology products used by the armaments industry given above, significantly contribute to the functionality of uniforms improving safety, range and effectiveness of military equipment, effectiveness of currently used high-energy materials and the striking force of thermobaric weapons (fuel-air) at a significantly reduced weight. Recently discovered nanoforms of elemental carbon (C) including fullerenes, nanotubes and graphene, with almost unlimited potential applications, are especially noteworthy.

\section{Concerns related to the release of engineered NPs to the environment}

A rapidly growing number of published monographs, research studies and patents on engineered NPs is accompanied by a growing number of publications showing their toxic, cytotoxic and genotoxic properties and hazards to the biotic environment [188, 203, 208, 215, 216]. Due to the rapid development of nanoscience and nanotechnology, in a dozen or so years, the Dekker Encyclopedia of Nanoscience and Nanotechnology has already had three editions (I - 2004, II - 2009 and III - 2016), each comprising 6 volumes [208].

The revolutionary changes in technology are reflected in the rapidly growing number of products fabricated using engineered NPs and a constantly expanding availability of products in both civil and military industries [19, 208, 217]. An increase in nanomaterial production increases the potential of releasing the NPs into the environment where they may interact with living organisms [208]. Due to high chemical reactivity and small size, by infiltrating the biosphere, NPs are a serious hazard to human health, a threat to international security and future of the military $[130,155,189,200,208,216,218,220-226]$. The negative impact of NPs on the environment is determined by their mobility depending on their solubility in ambient conditions, humidity and temperature, diffusion, susceptibility to coagulation and, as a result, deposition [224-230].

A serious source of concern is a growing number and range of marketed daily-use products containing engineered NPs with unknown impact on health and environment $[175,208]$. The analyses show that NPs can be found everywhere in the biosphere (air, water and soil) and in all living organisms [130, 175, 200, 205, 208, 215, 216, 223-229]. There are insufficient data on toxicity [203, 215, 218, 221, 224, 230], cytotoxicity [231, 232], genotoxicity [216, 218, 232] immunotoxicity, oxidative stress and latency time of NPs [208]. The hazards are widely monitored and discussed, and are the subject of protests against marketing nanoproducts, similar to the recent campaigns against GMOs (Genetically Modified Organisms). The knowledge of chemical and physical properties of a specific substance in macro scale [224] can be of some help in determining the hazards related to its use in the nanoscale [233].

The main routes of nanoparticle exposure are:

- respiratory - with the respiratory system's efficiency rapidly decreasing with increasing particle dispersion, Dusts [224] and NPs [200, 208, 233] are known to settle in the lungs using a mode of action similar to asbestos fibres [234].

The potential results include respiratory system disorders (pneumoconiosis, lung tumours), vascular system disorders and allergic reactions [200, 208, 215, 218, 220, 222-225, 230-231]. NPs with sizes similar to the biological structures may be absorbed by the cell by endocytosis, a specific mode of transport of larger particles to the inside of the cells, where vacuoles are formed [200, 208].; 
- dermal - the NPs penetrate the skin, as shown in the example of creams containing $\mathrm{TiO}_{2} \mathrm{NPs}^{2}[200,203,208$, $215,216,232,235,236]$. NPs may penetrate organisms via transport proteins or through ion channels and may bind to intracellular organelles [236, 208],

- digestive - through the alimentary tract with water [200, 208, 227-232, 237],

- nanoparticle crossing the blood-brain barrier [236, 238],

- NPs used as a carrier of other toxic substances [200, 208, 239, 240].

A specific group of hazards of real concern are the military applications of NPs including:

a) potential use of advanced military techniques by terrorist organisations (nano-terrorism) [155, 200, 208, 238],

b) new types of weapons of mass destructions in form of capsules transported in human bodies, plants or by nanorobots [156, 208, 220],

c) ability to design nanomaterial-based difficult to detect weapons or high-energy substances $[12,39,40,188$, 200, 208, 228],

d) data-gathering nanosensors used by terrorists [188, 208, 216, 220],

e) developing various devices preventing access to confidential information and test results [208],

f) social and ethical concerns [240-245].

Literature includes publications discussing the need to take action to protect society against products of nanotechnology including:

- monitoring the testing carried out by governments and private companies [203, 208, 216, 240, 244],

- extensive interdisciplinary tests on the interaction of engineered NPs with the biosphere $[15,151,200,208$, $216,227,246,247]$

- close cooperation between civil and military sectors [208, 242, 248],

- ensuring protection of information and test results of research institutes [15, 151, 200, 208],

- infiltration of terrorist organizations [31, 208],

- developing legal regulations on nanomaterials, nanoproducts and nanoobjects [208, 248],

- developing the characteristics (chemical, physical and biological) of NPs and methods used in the measurements of nanomaterials for reliable evaluation of their negative impact [208, 249-251],

- increasing society's ecological awareness through mass media [208].

\section{Summary}

The dynamic development of nanoscience and nanotechnology has led to revolutionary changes in many areas of science and industry, raising a great deal of hope for its potential to solve a wide range of problems of the modern world. Nanostructural materials, also referred to as the engineering NPs - the products of nanotechnology - show unique physical, chemical, biological and mechanical properties and effects compared to their macro equivalents. They have found practical applications in civil and military sectors with many examples presented in this study. The latest data on the development of nanotechnology, nanoproducts and nanobusiness are included in the OECT report of November 2017 which shows that the investments in research and development in nanotechnology was growing by $8 \%$ annually [252]. The difficulties in developing methods to synthesize engineered NPs for manufacturing on a technical scale are a key issue. The NPs are usually obtained on a laboratory scale which means they are expensive, the synthesis times are long and there may be issues with the repeatability of the synthesis method used. The actions undertaken aim to standardize the nanoparticle synthesis methods, whereas the surface modifications are aimed to increase homogeneity, monodispersity and stability.

A rapidly growing number of practical applications of engineering NPs and a real possibility of infiltrating the environment is a serious concern, reflected in numerous publications and protests [253, 254]. Apart from the unquestionable advantages of nanotechnology, the public will be exposed to well documented toxic, cytotoxic and genotoxic properties of NPs. There are numerous appeals to undertake studies of the hazards caused by the presence of NPs in the biosphere and develop legal regulations on practical applications of NPs. Power engineering and mass storage represent the main future applications of nanomaterials. 


\section{References}

[1] Nanomaterials and Nanochemistry. Bréchignac C., Houdy P., Lahmani M. Eds., Berlin/Heidelberg: Springer-Verlag, 2001.

[2] Nanomaterials: Synthesis, Properties and Applications. Edelstein A.S., Cammaratra R.C. Eds., London: Taylor \& Francis, 1998.

[3] Nanostructured Materials. Selected Synthesis Methods, Properties and Application. Knauth Ph., Schoonman J. Eds., Kluwer, 2004.

[4] Nanoscale Materials in Chemistry. Klabunde K.J. Ed., New York: J. Willey, 2008.

[5] Vollath D. Nanomaterials: An Introduction to Synthesis, Properties and Application. Weinheim: J. Willey$\mathrm{VCH}, 2008$.

[6] Cadermartini L., Ozin G.A. General Nanochemistry. Concepts. (in Polish) Warsaw: PWN, 2011.

[7] Tang Z., Sheng P. Nanoscale Phenomena, Basic Science to Device Applications. Berlin/Heidelberg: Springer-Verlag, 2008.

[8] Gullapalli S., Wong M.S. Nanotechnology: A Guide to Nano-objects. Chem. Eng. Prog. 2011, 107(5): 28-32.

[9] Ostrikov K., Neyts E.C., Meyyappan M. Plasma Nanoscience: from Nano-solids in Plasmas to Nanoplasmas in Solids. Adv. Phys. 2013, 62: 113-224.

[10] Tjong S.C., Chen H. Nanocrystalline Materials and Coatings. Mater. Sci. Eng. 2004, 45(1-2): 1-88.

[11] Prior M.H. Size Reduction, Principles of Powder Technology. Rhodes M. Ed., Chichester: J. Willey, 1990.

[12] Ramsden J.J. Applied Nanotechnology. $1^{\text {st }}$ ed., Elsevier, 2012.

[13] Kelsal R.W., Hamley I.W., Geoghegan M. Nanotechnologies. (in Polish) Warsaw: PWN, 2008.

[14] Taniguchi N. Nanotechnology. Integral Processing Systems for Ultra Precision and Ultra-fine Products. Oxford: Oxford Science Publishing, 1996.

[15] Manalis A.G. Recent Advances in Nanotechnology. J. Mater. Process. Technol. 2007, 18(1-3): 52-58.

[16] Ramsden J.J. Nanotechnology for Military Applications. Nanotechnol. Perceptions 2012, 8: 99-131.

[17] Kurzydłowski K., Lewandowska M. Engineered Structural and Functional Nanomaterials. (in Polish) Warsaw: PWN, 2010.

[18] Christian P., van der Kammer F., Baalousha M., Hofmann T. Nanoparticles: Structure, Properties, Preparation and Behaviour in Environmental Media. Ecotoxicology 2008, 17(5): 326-343.

[19] Zarko V., Gromow A. Energetic Nanomaterials. Characterization and Application. $1^{\text {st }}$ ed., Elsevier, 2016.

[20] Kohler M., Fritzsche W. Nanotechnology, An Introduction to Nanostructuring Techniques. Weinheim: Wiley-VCH Verlag GmbH \& Co. KGaA, 2007.

[21] Pang S.C., Kho S.Y., Chin S.F. Fabrication of Magnetite/Silica/Titania Core Shell Nanoparticles. J. Nanomater. 2012, 20: 1-6.

[22] Aumann C.E., Skofronick G.L., Martin J.A. Oxidation Behavior of Aluminum Nanopowders. J. Vac. Sci. Technol., B 1995, 13(2): 1178-1183.

[23] Thostenson E., Li C., Chou T. Nanocomposites in Context. Compos. Sci. Technol. 2005, 65(3-4): 491-516.

[24] Gash A.E., Simpson R.L., Tillotson T.M., Satcher J.H., Hrubesh L.W. Making Nanostructured Pyrotechnics in a Beaker. Proc. $27^{\text {th }}$ Int. Pyrotechnic Sem., Grand Junction, Colorado, 2000, 41-53.

[25] Martin J.A., Muray A.S., Busse J.R. Metastable Intermolecular Composites. Warhead Technol. 1998, 179-191.

[26] Foltynowicz Z. New Trends in Industrial Commodity Science. [in:] Packaging Commodity Science - Logistics), (in Polish) Foltynowicz Z., Jasiczak J., Szyszka G. Eds., Poznań: Poznań University of Economics and Business, 2008, 58-72.

[27] Pietrzak R., Wachowski L. Areas of Potential Practical Applications of Nanomaterials. [in:] Waste and Packaging - New Legal Regulations and Obligations. (in Polish) Wachowski L. Ed., Poznań: Explanator, 2013, Ch. 1/6, pp. 1-15.

[28] Nanotechnology Market 2017 Share, Trend, Segmentation and Forecast to 2020. https://www.einpresswire. 
com/article/370346275/nanotechnology-market-2017-share-trend-segmentation-and-forecast-to-2020 [retrieved 20.11.2017].

[29] Project on Emerging Nanotechnologies. An Inventory of Nanotechnology-based Consume Products Currently on the Market. Woodrow Wilson International Centre for Scholars. http://www. nanotechproject. org/inventories/consumer/ [retrieved 04.2011].

[30] Vance M.E., Kuiken T., Vejerano E.P., McGinnis S.P., Hochella Jr. M.F., Rejeski D., Hull M. Nanotechnology in the Real World: Redeveloping the Nanomaterial Consumer Products Inventory. Beilstein J. Nanotechnol. 2015, 6: 1769-1780.

[31] New Nanotech Products Hitting the Market at the Rate of 3-4 Per Week. http://www.nanotechproject.org/ news/archive/6697/ [retrieved 20.11.2017].

[32] Puszyński J.A. Advances in the Formation of Metallic and Ceramic Nanopowders. [in:] Powder Materials: Current Research and Industrial Practices. 2000, 89-105.

[33] Shenhar R., Rotello V.M. Nanoparticles: Scaffolds and Building Blocks. Acc. Chem. Res. 2003, 36: 549-561.

[34] Yaghmaee M.S., Shokri B., Rahimipour M.R. Size Dependence Surface Activity of Metallic Nanoparticles Plasma Processes. Polym. 2009, 6: 876-832.

[35] Gromov A., Ilyin A., Förter-Barth U., Teipel U. Characterization of Aluminum Powders: Aluminum Nanopowders Passivated by Non-inert Coatings. Propellants Explos. Pyrotech. 2007, 31(4): 401-409.

[36] Aumann C.E., Skofronick G.L., Martin J.A. Oxidation Behavior of Aluminum Nanopowders. J. Vac. Sci. Technol., B: Nanotechnol. Microelectron.: Mater., Process., Meas., Phenom. 1995, 13(3): 1178-1183; https://doi.org/10.1116/1.588232.

[37] Cliff M., Tepper F., Lisetsky V. Ageing Characteristics of Alex ${ }^{\circledR}$ Nanosize Aluminum. AIAA Proc. 37th Joint Propulsion Meeting, Salt Lake City, 2001, 3287.

[38] Nanomaterials: Moving towards stabilization. Eur. Business Rev. 2011, (July-August): 70-72.

[39] Klapötke T.M. Chemistry of High-Energy Materials. Berlin: Walter de Gruyter, 2011; ISBN 978-3110273588.

[40] Berner M.K., Zarko V.E., Talawar M.B. Nanoparticles of Energetic Materials: Synthesis and Properties. Combust. Explos. Shock Waves 2013, 49(6): 625-647.

[41] Teipel U. Energetic Materials: Particle Processing and Characterization. Weinheim: Wiley-VCH, 2005; ISBN 978-3-527-30240-6.

[42] Huber D.L. Synthesis, Properties, and Applications of Iron Nanoparticles. Small 2005, 1(5): 482-501.

[43] Koplowitz D.A., Jiang G.Q., Gaskell K. Synthesis and Reactive Properties of Iron Oxides Coated Nanoaluminum. J. Energ. Mater. 2014, 32(2): 95-105.

[44] Karagedov G.R, Lyakhov N.Z. Production and Sintering of a Nanocrystalline Powder of $\alpha-\mathrm{Al}_{2} \mathrm{O}_{3}$. Khim. Interes. Ust. Razv. 1999, 7(3): 229-238.

[45] Przybyszewska M., Zaborski M. Nanoparticle Zinc Oxide, Synthesis, Properties and Applications. (in Polish) Przem. Chem. 2009, 88(2): 154-161.

[46] Polizzi S., Battagliarin M., Bettinelli M., Speghini A., Fagherazzi G. Investigation on Lanthanide-doped $\mathrm{Y}_{2} \mathrm{O}_{3}$ Nanopowders Obtained by Wet Chemical Synthesis. J. Mater. Chem. 2002, 12: 742-747.

[47] Stöber W. Controlled Growth of Monodisperse Silica Spheres in the Micron Size Range. J. Colloid Interface Sci. 1968, 26: 62-69.

[48] Wang Y.P., Zhu W.J. Yang X.P., Lu L.D., Wang X. Preparation of NiO Nanoparticles and Their Catalytic Activity in the Thermal Decomposition of Ammonium Perchlorate. Termochim. Acta 2005, 437(1-2): 105-109.

[49] Gusew A.I. Nanocrystalline Materials: Synthesis and Properties. [in:] Dekker Encyclopedia Nanoscience and Nanotechnology. Vol. 4, New York/Boca Raton: Francis \& Taylor, 2009, 2621.

[50] Gash A.E., Tillotson T.M. Poco J.F., Satcher Jr. J.H., Hrubesh L.W., Simpson, R.L. New Sol-gel Synthetic Route to Transition and Main-group Metal Oxide Aerogels Using Inorganic Salt Precursors. J. Non-Cryst. Solids 2001, 285: 22-28. 
[51] Jurczyk M., Jakubowicz J. Ceramic Nanomaterials. (in Polish) Poznań: Wyd. Politechniki Poznańskiej, 2004; ISBN 8371435436.

[52] Chemistry of advanced materials. Interante L.V., Hampten-Smith M.J. Eds., New York: Willey VCH, 1998.

[53] Lach E., Wolf T., Scharf M. Submicro and Nano Ceramic as Ballistic Protective Material. Mechanic 2015, 88(2): 45-56.

[54] Rosenberg Z., Dekel E. Terminal Ballistics. Heidelberg: Springer Verlag, 2012.

[55] Jedliński Z. Novel Nanopolymers - Useful Drug Carriers for Medical Applications. Inżynieria Biomateriałów 2005, 47: 38-39.

[56] Aguilar J.O., Bautista-Quijano J.R., Aviles F. Influence of Carbon Nanotube Clustering on the Electrical Conductivity of Polymer Composite. eXPRESS Polymer Lett. 2010, 4(5): 292-299.

[57] Tsay T.Y. Polyethylene Terephtalate Clay Nanocomposite. [in:] Polymer-clay Nanocomposite. Pinavaia T.J., Beek G.W. Eds., Chichester: Willey Ltd., 2000.

[58] Theny B.K.G. Formulation and Properties of Clay-Polymer Complexes. Elsevier, 1979.

[59] Glebov E., Yuan L., Kishtopa L. Coating of Metal Powders with Polymers in Supercritical Carbon Dioxide. Ind. Chem. Res. 2001, 40(19): 4057-4068.

[60] http://moto.pl/MotoPL/1,88389,19038388,porsche-tequipment-metamorfoza-uzywanej-911-ki.html (in Polish) [retrieved 24.11.2017].

[61] Zao S., Malfait J., Demilecan A., Zhang Y., Brunner S., Huber L., Tigmant P., Rigacci T., Bultova T., Koelbel M.M. Strong Thermally Insulating Biopolymer-Silica Aerogel Hybrids by Cogelation of Silica Acid with Pectin. Angew. Chem. Int. Ed. 2015, 54: 14282-14286.

[62] Sakiyama-Elbert S.E., Hubbell J. Functional Biomaterials: Design of Novel Biomaterials. Ann. Rev. Mater. Res. 2001, 31: 183-201.

[63] Stodolak-Zych E., Frączek-Szczypta A., Błażewicz M. Polymer-Ceramic Nanocomposites in Bone Surgery. (in Polish) Materiały Kompozytowe Stosowane w Przemyśle 2011, 3: 54-58.

[64] Stodolak-Zych E., Gadomska K., Łącz A., Boguń M. Polymer-Ceramic Composition for Application in the Bone Surgery. J. Phys. Conf. Ser. 2009, 146(1): 1-6.

[65] Bordes P., Pollet E., Averous L. Nano Biocomposites: Biopolimer Polyester Nanoclay. Science 2009, 34(2): 125-155.

[66] Popov V.N. Carbon Nanotubes: Properties and Applications. Mat. Sci. Eng. R. 2004, 43(3): 61-102.

[67] Collins P.G. Nanotubes for Electronics. Sci. Am. 2000: 67-69.

[68] Hong S., Myung S. Nanotube Electronics: A Flexible Approach to Mobility. Nat. Nanotechnol. 2007, 2(4): 207-208.

[69] Charlie J.C., Roche S. Electronic and Transport Properties of Nanotubes. Rev. Mod. Phys. 2007, 79(2): 677-732.

[70] Wang X., Li Q., Xie J., Jin Z., Wang J., Li Y., Jiang K., Fan S. Fabrication of Ultralong and Electrically Uniform Single-walled Carbon Nanotubes on Clean Substrates. Nano Lett. 2009, 9(9): 3137-3141.

[71] Dekker C. Carbon Nanotubes as Molecular Quantum Wires. Phys. Today 1999, 52(5): 22-28.

[72] Menon M. Carbon Nanotube: Nanoscale Metal-Semiconductor-Metal Contact Devices. Phys. Rev. Lett. 1997, 79: 4453-4456.

[73] Smith B.W., Monthioux M.L., David E. Encapsulated C-60 in Carbon Nanotubes. Nature 1998, 396(6709): 323-324.

[74] Tang Z.K., Zhang L., Wang N., Zhang X.X., Wen G.H., Li G.D., Wang J.N., Chan C.T., Sheng P. Superconductivity in 4 Angstrom Single-walled Carbon Nanotubes. Science 2001, 292: 2462-2465.

[75] Takesue I., Haruyama J., Kobayashi N., Chiashi S., Maruyama S., Sugai T., Shinohara H. Superconductivity in Entirely End-bonded Multiwalled Carbon Nanotubes. Phys. Rev. Lett. 2006, 96(5): 057001.

[76] Star A. Nanotube Optoelectronic Memory Devices. Nano Lett. 2004, 4(9): 1587-1591.

[77] Karousis N., Tagmatarchis N., Tasis D. Current Progress on the Chemical Modification of Carbon Nanotubes. Chem. Rev. 2010, 110(9): 5366-5397. 
[78] Pacios P.M. Carbon Nanotubes as Platforms for Biosensors with Electrochemical and Electronic Transduction. Heidelberg: Springer, 2012.

[79] Bratcher M., Pesce-Rodriguez R., Kaste P., Ramaswamy A.L. Nanotube Modification of Energetic Materials. Proc. $38^{\text {th }}$ Meeting of the JANNAF Combustion Subcommittee, Destin, FL, 2002.

[80] Matthas L., Pulci O., Bechstedt F. Massive Dirac Quasiparticles in the Optical Absorbance of Graphene Silicene, Germane and Tinene. J. Phys. Condensed Matter. 2013, 25(39): 395-305.

[81] Roome N.J., Carrey J.D. Beyond Graphene: Stable Elements Monolayers of Silicen and Germanene. ACS Appl. Mater. Interf. 2014, 6(10): 7743-7750.

[82] Astruc D. Nanoparticles in Catalysis. Wiley VCH, 2008.

[83] Sarbak Z. Inorganic Nanoporous Materials. (in Polish) Poznań: Wyd. Nauk. UAM, 2010; ISBN 978-83-232-2004-6.

[84] Vollath D. Nanoparticles-Nanocomposites-Nanomaterials. Willey VCH, 2013.

[85] Hodge A.M., Balk T.J. Mechanical Properties of Nanoporous Gold. [in:] Nanoporous Gold: From an Ancient Technology to a High-Tech Material. Wittstock A., Biener J., Erlebacher J., Bäumer M. Eds., Royal Society of Chemistry, 2012, pp. 51-68; ISBN 978-1-84973-374-8.

[86] Wittstock A., Baumer M. Catalysis by Unsupported Skeletal Gold Catalysis. Acc. Chem. Res. 2014, 47: 731-739.

[87] Odrożek K., Maresz K., Koreniuk A., Mrowiec-Bidoń J. Gold Nanoparticles as Active Catalyst of Glucose Oxidation. (in Polish) Prace Naukowe Instytutu Inżynierii Chemicznej PAN 2013, 17: 105-115.

[88] Caroll M.K., Anderson A.M., Gorka C.A. Preparation Silica Aerogel via a Rapid Supercritical Extraction Method. J. Visualized Experiments 2014, 84: e51421.

[89] Zieliński R. Surfactants. Structure, Properties and Applications. (in Polish) $3^{\text {rd }}$ ed., Poznań: Wyd. Uniwersytetu Ekonomicznego, 2017; ISBN 9788374179263.

[90] Lasoń E., Ogonowski J. Encapsulation in Cosmetics. (in Polish) Towaroznawcze Problemy Jakości 2010, 4(25): 97-105.

[91] Runowski M. Nanotechnology, Nanomaterials, Nanoparticles: Multifunctional Core/Shell Structure. CHEMIK 2014, 9: 764-769.

[92] Menon M. Carbon Nanotube: Nanoscale Metal-Semiconductor-Metal Contact Devices. Phys. Rev. Lett. 1997, 79: 4453-4456.

[93] Lu W., Lieber C.M. Nanoelectronics from the Bottom Up. Nat. Mater. 2007, 6: 841-850.

[94] Słoma M. Carbon Nanomaterials in Printed Circuit Boards. (in Polish) Warsaw: Wyd. Politechniki Warszawskiej, 2017.

[95] Margillo J.F. Nanotechnology 101. London: Greenwood Press, 2007.

[96] Advances Nanoengeneering, Materials and Assembly. [in:] Royal Society Series Advances in Science. Davies A.G., Thompson J.M.T. Eds., Vol. 3, Imperial College Press, 2007.

[97] Czerwińska M. Applications of Nanomaterials in Armaments Industry. (in Polish) CHEMIK 2014, 68(6): 536-543.

[98] Tiwari A. Military Nanotechnology. Int. J. Eng. Sci. Adv. Technol. 2012, 2(4): 825.

[99] McGovern C. Commoditization of Nanomaterials. Nanotechnol. Perceptions 2010, 6: 155-178.

[100] Nanomaterials: Moving towards Stabilization. Eur. Business Rev. 2011, July-August: 70-72.

[101] Nanotechnology in Construction. Bittnar Z., Bartos P.J.M., Nemecek J., Smilauer V., Zeman J. Eds., Springer Verlag, 2009; ISBN 978-3-642-00980-8.

[102] Fic S., Kłonica M., Szewczak X. Effect of Hydrophobization on the Durability of Building Ceramics. (in Polish) Polimery 2016, 61(1): 46-48.

[103] Czarnecki L. Nanotechnology in Construction Industry. (in Polish) Przeglad Budowlany 2007, 1: 40-53.

[104] Choma J., Dziura A., Jamioła D., Nyga P., Jaroniec M. Synthesis of Gold Nanoparticles on the Surface of Colloidal Silica. (in Polish) Ochrona Środowiska 2010, 32(3): 3-6.

[105] Choma J., Jedynak K., Górka J., Jaroniec M. Adsorption Properties of Mesoporous Carbons with Titanium Dioxide Nanoparticles Obtained in the Presence of Block Copolymers. (in Polish) Ochrona Środowiska 
2010, 32(4): 3-9.

[106] Upadhyayula V.K.K., Deng S., Mithell M.C., Smith G.B. Application of Carbon Nanotube Technology for Removal of Contaminants in Drinking Water: A Review. Sci. Total Environ. 2009, 408(1): 1-13.

[107] Jiang C., Wang R., Ma W. The Effect of Magnetic Nanoparticles on Microcystis aeruginosa Removal by a Composite Coagulant. Colloids Surf., A 2010, 369(1-3): 260-267.

[108] Krishnaraj C., Jagan E.G., Rajasekar S., Selvakumar P., Kalaichelvan P.T., Mohan N. Synthesis of Silver Nanoparticles using Acalypha indica Leaf Extracts and Its Antibacterial Activity Against Water Borne Pathogens. Colloids Surf., B 2010, 76(1): 50-56.

[109] Płaza G., Kowalska E., J. Radomska J., Czerwosz E., Jangid K., Gawior K., Ulfig K., Janda-Ulfig K. The Effects of Multi-walled Carbon Nanotubes on Bacillus bacteria Growth and Production of Biosurfactants. (in Polish) Ochrona Środowiska 2009, 31(1): 21-24.

[110] Wang J., Zheng S., Shao Y., Liu J., Xu Z., Zhu D. Amino-Functionalized $\mathrm{Fe}_{3} \mathrm{O}_{4}: \mathrm{SiO}_{2} \mathrm{Core}_{\text {-Shell Magnetic }}$ Nanomaterial as a Novel Adsorbent for Aqueous Heavy Metals Removal. J. Colloid Interface Sci. 2010, 349: 293-299.

[111] Qui X., Alvarez P.J.J., Li Q. Applications of Nanotechnology in Water and Water Treatment. Water Res. 2013, 47(12): 3931-3946.

[112] Gebhard A., Knör N., Haupert F., Schlarb A. Nanopartikelverstärkte Hochleistunsthermoplaste für extreme tribologische Belastungen im Automobilbau. Tribol. Schmierungstech. 2008, 55(4): 28-32.

[113] Quality Improvements of Technological Processes. (in Polish) Żaba K. Ed., Kraków: Wyd. Nauk. AKAPIT, 2012; ISBN 978-83-60958-95-7.

[114] Bąk Ł., Śliwiński T. Protective Coatings -Applications in Car Industry. (in Polish) Zesz. Nauk. Politechniki Śląskiej Ser. Transport 2013, 78: 5-12.

[115] Car Cosmetics. (in Polish) waw.myjauto.pl/category/29/ nanoterchnologia.html [retrieved 20.11.2017].

[116] Głód D., Adamczak M., Bednarski W. Selected Aspects of Using Nanomaterials in Food Production. (in Polish) Żywność, Nauka, Technologia, Jakość 2014, 5(96): 36-52.

[117] Rodewald D. Characteristics of Cosmetic Products Containing Nanosilver Available on the Polish Market. (in Polish) Conf. Mater. Interdisciplinary Scientific Conf. for PhD Students, Hradec Králové, Czech Rep., 2011.

[118] Goel A., Kapoor S., Raman R., Pascal R.M.J., Kim H.-W., Fetrrerina J.M.F. Alkali-free Bioactive Glasses for Bone Yissue Engineering: a Preliminary Investigation. Acta Biomater. 2012, 18(11): 361-372.

[119] Bioactive Glasses, Materials, Properties and Applications. Yanen H.O. Ed., Woolhead Pub. Ltd., 2011.

[120] Dagdeviren C., Yang B.C., Su Y., Tran P.L., Joe P., Anderson E., Xia J., Doraisany V., Dandeshti B., Feng X., Lu B., Poston R., Khalpe Z., Ghaffan R., Huang Y., Stepian M.J., Rogers J.A. Conformal Piezoelectric Energy Harvesting a Storage from Motions of Heart Lung and Diaphragm. Proc. Nat. Acad. Sci. USA (PNAS) 2014, 111(5): 1927-1932.

[121] Gourav G., Ankur K., Rahul T., Sachin K. Applications and Future of Composite Materials: Review. Int. J. Innovative Res. Sci., Eng. Technol. 2016, 5(5): 6908-6911.

[122] Tjong S.C., Chen H. Nanocrystalline Materials and Coatings. Mater. Sci. Eng. 2004, 45(1-2): 1-88.

[123] Wang F., Banerjee D., Liu Y., Chen X., Liu X. Upconversion Nanoparticles in Biological Labelling, Imaging, and Therapy. Analyst 2010, 135: 1839-1854.

[124] Liu L., Guo G., Jayanthi C., Wu S. Colossal Paramagnetic Moments in Metallic Carbon Nanotori. Phys. Rev. Lett. 2002, 88(21): 217206.

[125] Pacios P.M. Carbon Nanotubes as Platforms for Biosensors with Electrochemical and Electronic Transduction. Heidelberg: Springer, 2012.

[126] Maliński T. Nitric Oxide and Nitro Oxidative Stress in Alzheimer's Disease. J. Alzheimer's Dis. 2007, 11(2): 207-218.

[127] Kozak A., Liu F., Funovics A., Jacoby A., Kubant R., Maliński T. Role of Peroxynitrite in Process of Vascular Tore Regulation by Nitric Oxide and Prostanaids a Nanothechnological Approach. Prostaglandins Leukot. Essent. Fatty Acids 2005, 71: 105-113. 
[128] Nano in Cosmetics and Personal Care. http://www.nanoandme.org/nano-products/cosmetics-andsunscreen/ [retrieved 25.11.2017].

[129] Rodewald D., Foltynowicz Z. Nanocosmetics as a New Trend in Cosmetics Industry. (in Polish) Świat Przemystu Kosmetycznego 2011, 4: 12-15.

[130] Makles Z. Nanomaterials - New Possibilities, New Hazards. (in Polish) Bezpieczeństwo Pracy 2005, 2: $2-4$.

[131] Rodewald D. Evaluation of Microbiological Resistance of Cosmetics in Nanosilver-modified Polymer Packaging. (in Polish) Doctoral Thesis, Poznań University of Economics and Business, 2014.

[132] Urbaniak W., Foltynowicz Z. Method for Obtaining Metal Nanoparticles Dispersed in the Inorganic Matrix. (in Polish) Patent PL 190289, 2005.

[133] Campos-Cuerva C., Zieba M., Sebastian V., Martínez G., Sese J., Irusta S., Contamina V., Arruebo M., Santamaria J. Screen-printed Nanoparticles as Anti-counterfeiting Tags. Nanotechnol. 2016, 27: 095702; DOI: $10.1088 / 0957-4484 / 27 / 9 / 095702$.

[134] Jakubiak P., Foltynowicz Z. Cellulose Derivative-based Polymer Nanocomposites and Their Production Methods. Patent AE 2/2006, 2006.

[135] Jakubiak P., Foltynowicz Z. Polymer Nanocomposites - Modern Solutions for Packaging Market. (in Polish) Opakowanie 2004, 6: 6-12.

[136] Foltynowicz Z., Kozak W., Fiedorow R. Studies of Oxygen Uptake on $\mathrm{O}_{2}$ Scavengers Prepared from Different Iron-containing Parent Substances. Packag. Technol. Sci. 2002, 15: 1-7.

[137] Foltynowicz Z., Kozak W., Urbaniak W. Oxygen Scavenger and Method of Fabrication. (in Polish) Patent PL 19082, 2007.

[138] Foltynowicz Z., Bardenshtein B., Sängerlaub S., Antvorskov H., Kozak W. Nanoscale, Zero valent Iron Particles for Application as Oxygen Scavenger in Food Packaging. Food Packag. Shelf Life 2017, 11: 7483; DOI: 10.1016/j.fps1.2017.01.003.

[139] Frydrych E., Foltynowicz Z., Kowalak S. Non-metallic Oxygen Absorbent. (in Polish) Patent PL 215298, 2013.

[140] Foltynowicz Z., Kozak W., Stoińska J., Urbańska M. Method of Nano-Iron Production and Its Application in Oxygen Absorption in Packaging and Oxygen Scavengers. (in Polish) Patent PL 227585, 2017.

[141] Foltynowicz Z., Kozak W., Stoińska J., Urbańska M., Muc K., Forysiak A., Kublicka K. Nanoiron Based Oxygen Scavengers. Patent JP 6093713, 2017.

[142] Foltynowicz Z., Kozak W., Stoińska J., Urbańska M. Method of Nano-Iron Production and Its Application in Oxygen Absorption in Packaging and Oxygen Scavengers. (in Polish) Patent PL 227096, 2010.

[143] Foltynowicz Z., Kozak W., Stoińska J., Urbańska M., Muc K., Kublicka K. Nanocomposite Oxygen Scavenger. (in Polish) Patent PL 397499, 2011.

[144] Foltynowicz Z., Kozak W., Stoińska J., Urbańska M., Muc K., Forysiak A., Kublicka K. Nanoiron Based Oxygen Scavengers. Patent WO 2012091587A1, 2012.

[145] Foltynowicz Z., Kozak W., Stoińska J., Urbańska M., Muc K., Forysiak A., Kublicka K. Nano- iron-based Oxygen Scavengers. Patent EP 2658666A1, 2013.

[146] Foltynowicz Z., Kozak W., Stoińska J., Urbańska M., Muc K., Forysiak A., Kublicka K. Nanoiron-based Oxygen Scavengers. Patent IL 227146, 2013.

[147] Foltynowicz Z., Kozak W., Stoińska J., Urbańska M., Muc K., Forysiak A., Kublicka K. Nanoiron-based Oxygen Scavenger. Patent US 2014004232A1, 2013.

[148] An Update on Nanotechnology in the USA. The Magazine Nano 2009: 15-24.

[149] Moore D. Be All You Can Be: the Nano-enhanced Army. The Magazine Nano 2009, 15-18.

[150] Kubota N. Propellants and Explosives. Thermochemical Aspects of Combustion. $2^{\text {nd }} e d$., Weinheim: J. Wiley-VCH, 2007.

[151] Christian P., van der Kammer F., Baalousha M., Hofmann T. Nanoparticles: Structure, Properties, Preparation and Behaviour in Environmental Media. Ecotoxicology 2008, 17(5): 326-343.

[152] Rossi C., Estève A., Vashishta P. Nanoscale Energetic Materials. J. Phys. Chem. Solids 2010, 71(2): 
57-58.

[153] Walley S.M., Field J.E., Greenway M.W. Crystal Sensitivities of Energetic Materials. Mater. Sci. Technol. 2006, 22: 402-413.

[154] Garstka J. Nanotechnology - a New Battlefield. (in Polish) Przeglad Wojsk Lądowych 2006, 8: 88-92.

[155] Altman J. Military Uses of Nanotechnology - Too much Complexity for International Security? Complexities 2008, 14(1): 62-70.

[156] Altman J. Military Uses of Nanotechnology: Perspectives and Concerns. Security Dialogue 2004, 35(1): 61-79.

[157] Comet M., Schnell F., Pichot V., Mory J., Risse B., Spitzer D. Boron as Fuel for Ceramic Thermites. Energy Fuels 2014, 28(6): 4139-4148.

[158] Glebov E., Yuan L., Kishtopa L. Coating of Metal Powders with Polymers in Supercritical Carbon Dioxide. Ind. Chem. Res. 2001, 40(19): 4057-4068.

[159] Gromov A., Ilyin A., Förter-Barth U., Teipel U. Characterization of Aluminum Powders: Aluminum Nanopowders Passivated by Non-inert Coatings. Propellants Explos. Pyrotech. 2007, 31(4): 401-409.

[160] Yaghmaee M.S., Shokri B., Rahimipour M.R. Size Dependence Surface Activity of Metallic Nanoparticles. Plasma Processes Polym. 2009, 6: 876-832.

[161] Shenhar R., Rotello V.M. Nanoparticles: Scaffolds and Building Blocks. Acc. Chem. Res. 2003, 36: 549-561.

[162] Thostenson E., Li C., Chou T. Nanocomposites in Context. Compos. Sci. Technol. 2005, 65(3-4): 491-516.

[163] Yuan Y., Jiang W., Wang Y.J. Hydrothermal Preparation of $\mathrm{Fe}_{2} \mathrm{O}_{3} /$ Graphene Nanocomposite and Its Enhanced Catalytic Activity of Thermal Decomposition of Ammonium Perchlorate. Appl. Surf. Sci. 2014, 303(1): 354-359.

[164] Zhigach A.N., Leipunsky I.O., Kudrov B.V. Aluminized HNIW-based Nanocomposite - Synthesis and Explosive Properties. Proc. European 2011 Seminar, Reims, France, 2011, Session S11b.

[165] Revell P.A. The Biological Effects of Nanoparticles. Nanotechnol. Perceptions 2006, 2: 283-298.

[166] Sindhu T.K., Sarathi R., Chakravarthy S.R. Generation and Characterization of Nano Process. Bull. Mater. Sci. 2007, 30(2): 187.

[167] Pragnesh D., Chaturvedi S. Nanocatalyst for Composite Solid Rocket Propellants. Germany: LAP LAMBERT Acad. Publish., 2010; ISBN 3838377214.

[168] Jayaraman K., Anand K.V., Chakravarthy S.R., Sarathi R. Effect of Nano-aluminum in Plateau- burning and Catalyzed Composite Solid Propellant Combustion. Combust. Flame 2009, 156(8): 1662-1673.

[169] Florczak B., Cudziło S. Catalytic Effect of Nano $\mathrm{Fe}_{2} \mathrm{O}_{3}$ on Burning Rate of Aluminized PBAN/ $\mathrm{NH}_{4} \mathrm{ClO}_{4} /$ HMX/Al Composite Propellant. (in Polish) Biul. WAT 2009, 58(4): 187-195.

[170] Kleppinger D.H. Potential for Powder Metallurgy Applications in Army Material. Progress in Powder Metallurgy 1971 P/M. [in:] Ordnance. New York: Metal Powder Industries Federation, 1971, 85.

[171] Ludyński Z., Nita Z. Fundamentals of Heavy Sinter Production Technology. (in Polish) Research and Development of New Structural Materials and Basic Technology for Military Armament Products Conf., Kołobrzeg, Poland, 1997, 15/1-15/20.

[172] Majewski T., Cudziło S., Czugała M. Combustion Synthesis of Tungsten and Rhenium Nanopowders for Heavy Alloys Applications. (in Polish) Biul. WAT 2009, 58(3): 9-16.

[173] https://www.globalsecurity.org/military/systems/munitions/index.html [retrieved 25.11.2017].

[174] Tungsten: The Perfect Metal for Bullets and Missiles. BBC News 2014, http://www.bbc.com/news/ magazine-28263683 [retrieved 25.11.2017].

[175] Musee N. Nanowastes and the Environment: Potential New Waste Management Paradigm. Int. Environ. 2011, 37: 112-128.

[176] http://tech.wp.pl/kat,130034,title,rosyjska-armia-i-policja-zosta-13.na-wyposazone-w-nanopancerze, wid,15898379, wiadomosc.html [retrieved 25.03.2014].

[177] Marcisz J., Garbarz B., Adamczyk M., Wiśniewski A. New-precitates Hardened Steels of Wide Range of Strength an Toughness and High Resistance to Piercing with Projectiles. Problems of Mechatronics, 
Armament, Aviation, Safety Engineering 2012, 4(10): 39-54.

[178] Stępień J., Garbarz B., Burdek M., Marcisz J., Burian W. Modern Steel Materials Used in Production of Cartridge-cases, Cartridges, Bodies of Rocket and Artillery Projectiles and Armour. (in Polish) Problemy Techniki Uzbrojenia 2009, 38(111): 15-26.

[179] Marcisz J., Garbarz B., Burian W., Wiśniewski A. The Mechanisms of Dynamic Deformation in Ultrahighstrength Nanostructured Steels for Armours. (in Polish) Problemy Techniki Uzbrojenia 2011, 118(2): 41-49.

[180] Garbarz B., Marcisz J., Adamczyk M., Wiśniewski A. Ultrahigh-strength Nanostructured Steels for Armours. Problems of Mechatronics, Armament, Aviation, Safety Engineering 2011, 1(3): 25-36.

[181] Garbarz B., Burian W., Marcisz J., Wiśniewski A. The Nano-duplex NANOS-BA Steel for Application in Construction of Armours. Problems of Mechatronics, Armament, Aviation, Safety Engineering 2011, 4(10): 7-22.

[182] Lince J.R. Tribology of co-Sputtered Nanocomposite $\mathrm{Au} / \mathrm{MoS}_{2}$ Solid Lubricant Films over a Wide Contact Stress Range. Tribol. Lett. 2004, 17: 419-428.

[183] Dey A., Sikder A.K., Talawar B.M., Chottopadhyay S. Towards New Directions in Oxidizers - Energetic Fillers for Composite Propellants: An Overview. Cent. Eur. J. Energ. Mater. 2015, 12(2): 377-399.

[184] Miziołek A.W., McNesby K.L., Russell R.S. Military Applications of Laser Induced Breakdown Spectroscopy (LIBS). Abstract Book for Pittcon, New Orleans, 2002.

[185] Xu J., Fisher, T.S. Enhancement of Thermal Interface Materials with Carbon Nanotube Arrays. Int. J. Heat Mass Transfer 2006, 49: 1658-1666.

[186] Son Y., Pal S.K., Tasciuk T.B., Ajayan P.M., Siegiel R.W. Thermal Resistance of the Native Interface between Vertically Aligned Multiwall Carbon Nanotube Arrays and Their $\mathrm{SiO}_{2} / \mathrm{Si}$ Substrate. J. Appl. Phys. 2008, 103: 024911.

[187] Unikrishman V.U., Reddy N., Banerjee D., Rostam-Abadin R. Thermal of Defective Enhance Defective Carbon-Nanotube Polimer Nanocomposites. Interaction Multiscale Mech. 2008, 1(4): 397-409.

[188] De Neve A. Military Use of Nanotechnology and Converging Technologies: Trends and Future Impacts. Royal High Institute for Defence Center for Security and Defence Studies, Focus Paper, 2009, 8: 1.

[189] Ratner D., Ratner M. Nanotechnology. A Gentle Introduction to the Next Big Idea. Prentice Hall Prof. Tech. Reference 2002, 102: 4-16.

[190] Chen Y., Li H., Sun Z. Development of Infrared Detectors using Single Carbon-nanotube-based Fieldeffect Transistors. IEEE Trans. Nanotechnol. 2010, 9: 582-589.

[191] Holt G.C. Negative Index of Refraction and Metamaterials. Nanotechnol. Perceptions 2008, 4: 201-205.

[192] Lezec H.J., Dionne J.H., Atwater H.A. Negative Refraction at Visible Frequencies. Science 2007, 316: 430-432.

[193] Seachman N.J., Williams L.C. Platen Cover for a Digital Document Scanner with Electrically Switchable Reflectance Modes. Patent US 5790211, 1998.

[194] Lopez R., Boatman L.A., Hayr T.E. Switchable Reflectivity on Silicon from a Composite $\mathrm{VO}_{2}-\mathrm{SiO}_{2}$ Protecting Layer. Appl. Phys. Lett. 2004, 85: 1410-1412.

[195] Hagn F., Eisolod L., Hardy J.G., Vendrely C., Coles M., Schreiber T., Kessler H. A Conserved Spider Silk Domain Acts as a Molecular Switch that Controls Fibre Assembly. Nature 2010, 465: 239-242.

[196] Cheng T.-W., Zeng Y.M., Wu Ch.-J. Analysis Tenable Negative Refraction in a Loss and Extrinsic Semiconductor. Appl. Optics 2015, 54(4): 658-662.

[197] Śmiałkowska-Opałka M. Future Warrior Concept. (in Polish) Techniczne Wyroby Wtókiennicze 2009, 17(1): 10-13.

[198] Hagn F., Eisoldt L., Harley J.G., Vendrely C., Coles M., Scheibel T., Kessler H. A Conserved Spider Silk Domain Acts as a Molecular Switch that Controls Fibre Assembly. Nature 465(7295): 239-242.

[199] Moore D. Be All You Can Be: the Nano-enhanced Army. The Magazine Nano 2009, 15: 18.

[200] Hannah W., Thompson P.B. Nanotechnology Risk and the Environment: A Review. J. Environ. Monit. 2008, 10(3): 291-300. 
[201] Brown M. Nanofibres Defuse Explosives. 2005, https://www.chemistryworld.com/news/NanofibresDefuse-Explosives/3002651.article [retrieved 20.11.2017].

[202] Hároz E.H., Rice W.D., Lu B.Y., Hauge R.M., Weisman R.M., Doorn S.K., Kono J. Enrichment of Armchair Carbon Nanotubes via Density Gradient Ultracentrifugation: Raman Spectroscopy Evidence. ACS Nano 2000, 4(4): 1955-1962.

[203] Bystrzejewska-Piotrowska G., Golimowski J., Urban P.I. Nanoparticles: Their Potentially Toxicity, Waste and Environmental Management. J. Waste Manage. 2009, 29: 2587.

[204] Klapötke T.M. Chemistry of High-energy Materials. $3^{\text {rd }}$ ed., Berlin/Boston: de Gruyter, 2015.

[205] Paduch J., Kuziak R., Krztoń H., Pospiech J. Synthesis and Properties of Nanomaterials Embedded in Iron Matrix. (in Polish) Archiwum Technologii Maszyn i Automatyzacji 2007, 27(1): 143-152.

[206] Military Reloads with Nanotech. 2005, https://www.technologyreview.com/s/403624/Military-Reloadswith-Nanotech/ [retrieved 20.11.2017].

[207] Kumar U., Sikarwar S., Sonker R.K., Yadar B.C. Carbon Nanotubes: Synthesis and Application in Solar Cell. J. Inorg. Organomet. Polym. Mater. 2016, 26(6): 1231-1242.

[208] Dekker Encyclopedia Nanoscience and Nanotechnology. $3^{\text {rd }}$ ed., Lyshevski S.E. Ed., CRS Press, 2016, Vol. I-VI.

[209] Muratore C., Hu J.J., Voevodin A.A. Adaptive Nanocomposite Coatings with a Titanium Nitride Diffusion Barrier Mask for High-temperature Tribological Applications. Thin Solid Films 2007, 550: 3638-3643.

[210] Muratore C., Hu J.J., Voevodin A.A. Tribological Coatings for Lubrication over Multiple Thermal Cycle. Surf. Coat. Technol. 2009, 203(8): 957-962.

[211] Rozmus M. Gradient Cermet Materials. (in Polish) Materiały Ceramiczne 2006, 58(4): 142-147.

[212] Chang T.-W., Zeng Y.M., Wu C.-J. Analysis Tenable Negative Refraction in a Loss and Extrinsic Semiconductor. Appl. Optics 54(4): 658-662.

[213] Wang X., Li Z., Xu W., Kulkarni S.A., Batabyal S.K., Zhang S., Cao A., Wong L.H. $\mathrm{TiO}_{2} \mathrm{Nanotube}$ Arrays Based Flexible Perovskite Solar Cells with Transparent Carbon Nanotube Electrode. Nano Energy 2015, 11: 728-735.

[214] Pradhan N.R., Talapatna S., Terrones M., Ajayan P.Y., Balicas L. Optoelectronic Properties Heterostructures: The Most Recent Developments Based on Graphene and Transitions Metal Dicholeogenides. Nanotechnology Magazine 2017, 11(2): 18-32.

[215] Borm P.J.A., Robbins D., Haubol S., Kuhibusch T., Fissan H., Donaldson K., Schins R., Stone V., Kreyling W., Lademann J., Hartmann J., Warheit D., Oberdorfer J. The Potential Risk of Nanomaterials: A Review Carried out for ECETOC. Part. Fibre Toxicol. 2006, 3(11): 1-25.

[216] Sahoo S.K., Parveen S., Panda J.J. The Present and Future of Nanotechnology in Human Health Care. Nanomedicine 2007, 3(1): 20-31.

[217] Kelly M.J. Nanotechnology and Manufacturability. Nanotechnol. Perceptions 2011, 7: 79-81.

[218] Revell P.A. The Biological Effects of Nanoparticles. Nanotchnol. Perceptions 2006, 2: 283-298.

[219] Huczko A. Carbon Nanotubes. (in Polish) Warsaw: BeL Studio, 2004; ISBN 8388442864.

[220] Tomczak J. Dangers of Nanotechnology. (in Polish) http:// www.Nanonet.pl/pl/index.php/ nanobiznes/ nanoryzyka/70-zagrożenia-wypływajace-z-Nanotechnologii [retrieved 25.03.2014].

[221] Ahamed M., Alsalhi M.S., Siddiqui M.K.J. Silver Nanoparticle Applications and Human Health. Clin. Chim. Acta 2010, 411: 1841-1848.

[222] Wachowski L., Kirszensztejn P. Chemical Environmental Hazards. [in:] Ecology Science Compendium. (in Polish) Strzałko J., Mossor-Pietraszewska T. Eds., $3^{\text {rd }}$ ed., Warsaw/Poznań: PWN, 2006, Ch. VII, pp. 313-356.

[223] vanLoon G.W., Duffy S.J. Environmental Chemistry: A Global Perspective. (in Polish) Warsaw: PWN, 2007.

[224] Hofman M., Wachowski L. Analysis of Platinum and Lead Content in Soil Along the Main Poznań Exit Routes. (in Polish) Ochrona Środowiska 2010, 32(3): 43-47.

[225] Pietrzak R., Wachowski L. Concerns Related to the Possible Adverse Effects of Nanoobjects on 
Environment and Human Life. [in:] Waste and packaging - New legal regulations and obligations. (in Polish) Wachowski L. Ed., Poznań: Forum, 2012, Ch. 2/4.5.1, pp. 1-13.

[226] Pietrzak R., Wachowski L. Classification of Nanowaste as a Tool to Determine Their Harmfulness. [in:] Waste and Packaging - New Legal Regulations and Obligations. (in Polish) Wachowski L. Ed., Poznań: Forum, 2012, Ch. 2/4.5.2, pp. 1-13.

[227] Łebkowska M., Załęska-Radziwiłł M. Occurence and Ecotoxicity of Nanoparticles. (in Polish) Ochrona Środowiska 2011, 33(4): 23-26.

[228] Moore M.N. Nanoparticles Present Ecotoxicological Risk for the Health of the Aquatic Environment? Environ. Int. 2006, 32(8): 967-976.

[229] Fröhlich E. Cellular Targets and Mechanisms in the Cytotoxic Action of Non-Biodegradable Engineered Nanoparticles. Curr. Drug Metab. 2013, 14: 976-988.

[230] Park M.V., Neigh A.M., Vermeulen J.P., de la Fonteyne L.J., Verharen H.W., Briedé J.J., van Loveren H., de Jong W.H. The Effect of Particle Size on the Cytotoxicity, Inflammation, Developmental Toxicity and Genotoxicity of Silver Nanoparticles. Biomaterials 2011, 32(36): 9810-9817.

[231] Świdzińska-Grajewska M.A. Nanoparticles (Part 1) - Products of Modern Technology and New Hazards in the Work Environment. (in Polish) Medycyna Pracy 2007, 58(3): 243-251.

[232] Beck R., Guterres S., Pohlmann A. Nanocosmetics and Nanomedicines. New Approaches for Skin Care. Berlin/Heidelberg: Springer-Verlag, 2011.

[233] Geiser M., Kreyling W.G. Deposition and Biokinetics of Inhaled Nanoparticles. Part. Fibre Toxicol. 2010, 7/2: 3-17.

[234] Wachowski L., Domka L. Sources and Effects of Asbestos and Other Mineral Fibers Presence in Ambient Air. Polish J. Environ. Stud. 2000, 9(6): 443-454.

[235] Tang Y., Han S., Liu H., Chen X., Huang L., Li X., Zhang J. The Role of Surface Chemistry in Determining in vivo Biodistribution and Toxicity of CdSe/ZnS Core-Shell Quantum Dots. Biomaterials 2013, 3: 8741-8755.

[236] Karlsson H.L. The Comet Assay in Nanotoxicology Research. Anal. Bioanal. Chem. 2010, 398(2): 651-666.

[237] Neal A.L. What Can Be Inferred from Bacterium-Nanoparticle Interactions about the Potential Consequences of Environmental Exposure to Nanoparticles? Ecotoxicology 2008, 17(5): 362-371.

[238] Altmann J., Gubrud M.A. Risks from Military Uses of Nanotechnology - the Need for Nanotechnology. Lecce 2002, 3/11-12.

[239] Love S.A., Maurer-Jones M.A., Thompson J.W., Lin Y.-S., Haynes C.L. Assessing Nanoparticle Toxicity. Annu. Rev. Anal. Chem. 2012, 5: 181-205.

[240] Moore D.F. Nanotechnology and the Military, Nanoethics: The Ethical and Social Implications of Nanotechnology. Allhoff F., Lin P., Moor J., Weckert J. Eds., Wiley-VCH, 2007.

[241] Altmann J., Gubrud M.A. Military, Arms Control, and Security Aspects of Nanotechnology. Discovering Nanoscale 2004, 269; ISBN 1-58603-467-7.

[242] Bennet-Woods D. Nanotechnology: Ethics and Society. CRS Press, 2008.

[243] Moore D.F. Nanotech in Warfare. Some Ethical Concerns. Nano Magazine 2012, 23(February): 14-17.

[244] Allhoff F., Lin P. What's So Special About Nanotechnology and Nanoethics? J. Appl. Phylosophy 2006, 20(2): 179-190.

[245] Lin P., Allhoff F. Against Unrestricted Human Enhancement. J. Evolution Technol. 2008, 18(1): 35-41.

[246] Stoccoro A., Karlsson H.L., Coppedè F., Migliore L. Epigenetic Effects of Nano Sized Materials. Toxicology 2013, 313: 3-14.

[247] Smopczyński T., Góralczyk K., Czaja K., Struciński P., Hernik A., Korcz W., Ludwicki J.K. Nanotechnology and Related Hazards. (in Polish) Roczniki Państwowego Zakładu Higieny 2009, 60(2): 101-111.

[248] Fairbrother A., Fairbrother J.R. Are Environmental Regulations Keeping up with Innovation? A Case Study of the Nanotechnology Industry. Ecotoxicol. Environ. Saf. 2009, 72(5): 1327-1330. 
[249] Hasselloev M., Readman J.W., Ranville J.F., Tiede K. Nanoparticle Analysis and Characterization Methodologies in Environmental Risk Assessment of Engineered Nanoparticles. Ecotoxicology 2008, 17(5): 344-361.

[250] Crane M., Handry R.D., Garrod J., Owen R. Ecotoxicity Test Methods and Environmental Hazard Assessment for Engineered Nanoparticles. Ecotoxicology 2008, 17(5): 421-437.

[251] Handy R.D., Owen R., Valsami-Jones E. The Ecotoxicology of Nanoparticles and Nanomaterials: Current Status, Knowledge Gaps, Challenges and Future Needs. Ecotoxicology 2008, 17(5): 315-325.

[252] Key Nanotechnology Indicators. http://www.oecd.org/sti/nanotechnology-indicators.htm.

[253] Foltynowicz Z. Nanocomposites - New materials in Packaging, New Type of Waste and New Concerns for Recycling. (in Polish) Recycling Logistics Conf., Wrocław: Poland, 2017.

[254] Nanotechnology: The Promises and Pitfalls of Science at the Nanoscale. https://www.acs.org/content/ dam/acsorg/membership/acs/benefits/extra-insights/nanotech-final-040816.pdf [retrieved 20.11.2017].

Polish version:

The study was originally published in Polish, in the Materiaty Wysokoenergetyczne (High Energy Materials) journal 2017, 9: 18-39. This article is available in Polish as a PDF at:

http://www.ipo.waw.pl/wydawnictwa/materialy-wysokoenergetyczne/MatWysokoenergetycznetom9/158.pdf

English version:

- Revised: November 21, 2020

- Published first time online: December 14, 2020 